\title{
Nanoindentation study of macerals in coals from the Ukrainian Donets Basin
}

\author{
Sanja Vranjes ${ }^{1,2}$, David Misch ${ }^{1}$, Thomas Schöberl ${ }^{3}$, Daniel Kiener ${ }^{2}$, Doris Gross ${ }^{1}$, and Reinhard F. Sachsenhofer ${ }^{1}$ \\ ${ }^{1}$ Department Applied Geosciences and Geophysics, Montanuniversitaet Leoben, Leoben, 8700, Austria \\ ${ }^{2}$ Department Materials Physics, Montanuniversitaet Leoben, Leoben, 8700, Austria \\ ${ }^{3}$ Erich Schmid Institute of Materials Science, Austrian Academy of Sciences, Leoben, 8700, Austria
}

Correspondence: Sanja Vranjes (sanja.vranjes@unileoben.ac.at)

Received: 29 May 2018 - Accepted: 26 July 2018 - Published: 7 August 2018

\begin{abstract}
This article discusses the mechanical properties of macerals in Carboniferous coals from the Ukrainian Donets Basin, covering a maturity range from 0.62 to $1.47 \% \mathrm{Rr}$ (vitrinite reflectance). The inherent inhomogeneity of geological samples requires characterization at the micro-/nanoscale, and hence material parameters, such as hardness $H$ and reduced elastic modulus $E_{\mathrm{r}}$, were obtained from twelve coal specimens via nanoindentation tests. Different material properties and maturity trends were acquired for the individual maceral groups (vitrinite, inertinite, liptinite). The results indicate that apart from maturity, multiple factors like microstructural features and depositional environment control the mechanical properties of macerals in coals. $H$ and $E_{\mathrm{r}}$ of vitrinites show a complex relationship with maturity due to additional influence of microstructural features such as nanoporosity or mineral inclusions and complex changes in the organic matter structure with increasing rank. The mechanical behaviour of inertinites is mainly controlled by the prevailing conditions (temperature, exposure) during paleowildfires. $E_{\mathrm{r}}$ and $H$ of liptinites are strongly influenced by transformational processes related to devolatilization at low to medium rank, as well as later hydrocarbon generation. Variations in the depositional environment (e.g. increased organic $\mathrm{S}$ content due to marine influence) might play an additional role.
\end{abstract}

\section{Introduction}

Coal is still of particular importance as a natural resource today and remains one of the most important energy sources for the production of electricity or in various metallurgical processes. Moreover, it is considered a substantial source for methane which not only represents a mining hazard but can also be utilized by modern unconventional production techniques (e.g. coal bed methane; CBM). However, the producibility of coal bed methane depends on mechanical properties and fracture behaviour of the hosting coals. Coals are constituted by distinct organic components referred to as macerals (vitrinite, liptinite, inertinite), and obtaining the mechanical properties of individual maceral particles is challenging due to their usually small size (often microscaled). Nevertheless, knowledge of maceral-specific properties is critical for the understanding of controlling factors on the overall mechanical properties of a certain coal sample. Borodich et al. (2015) and Epshtein et al. (2015) proved the suitability of nanoindentation for the determination of mechanical properties of individual coal macerals. The great advantage of nanoindentation compared to other indentation testing approaches is the small required testing volume which allows analyses of material parameters like hardness $(H)$ and reduced elastic modulus $\left(E_{\mathrm{r}}\right)$ in areas that are considered highly inhomogeneous at the micro-scale (Oliver and Pharr, 1992).

In an attempt to determine material parameters of individual macerals and to study maturity-related changes, nanoindentation tests were carried out on twelve Carboniferous coal samples from the Ukrainian Donets Basin (Fig. 1). The Donets Basin hosts one of the most important coal fields worldwide and extends over an area of $60000 \mathrm{~km}^{2}$ (Sachsenhofer et al., 2012). The selected coals cover a broad maturity interval of $0.62-1.47 \% \mathrm{Rr}$ (vitrinite reflectance) and were intensively investigated regarding their depositional environment, paleoecology, geochemistry and petrography dur- 


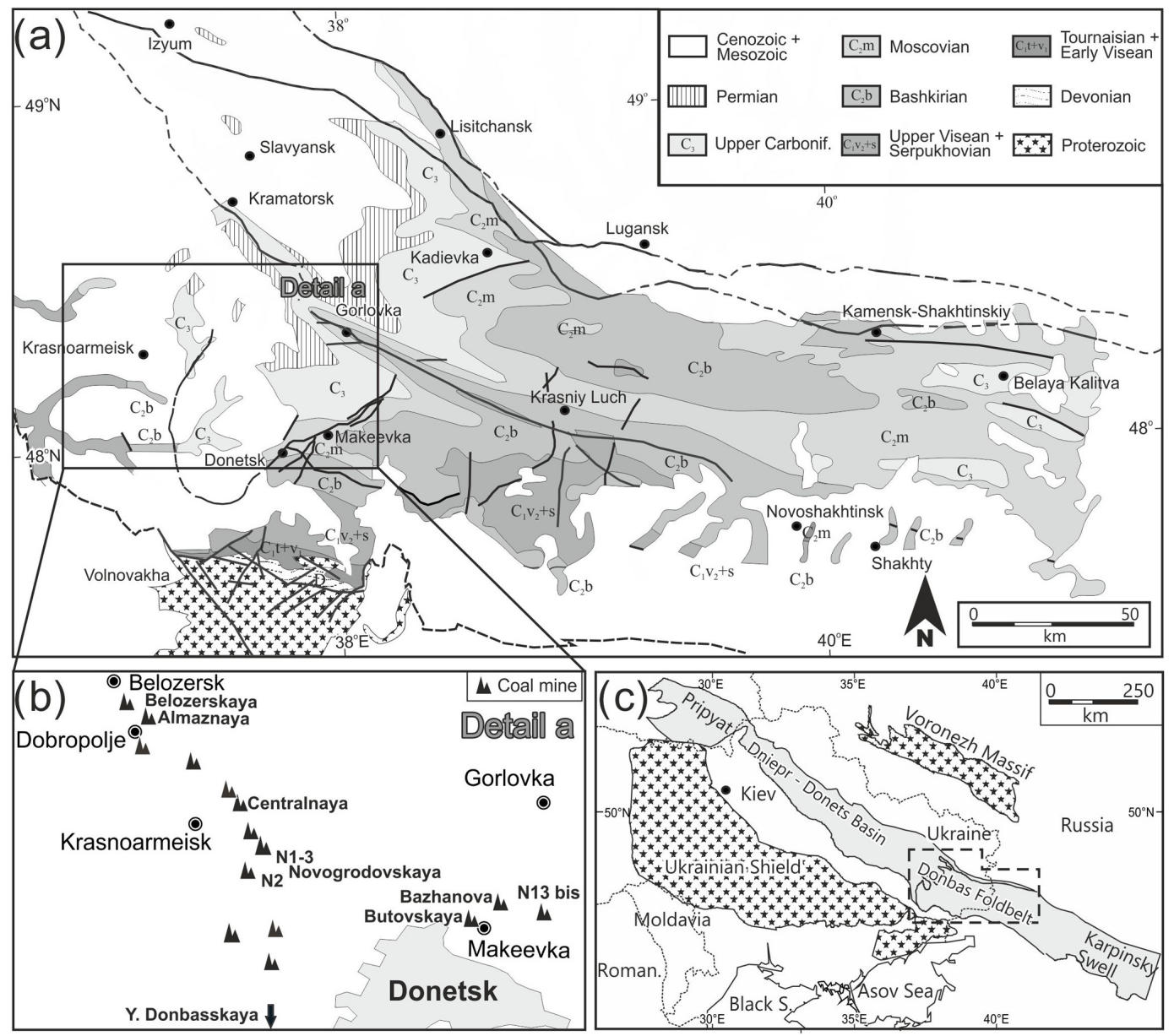

Figure 1. (a) Geological map of the Donets Basin (after Sachsenhofer et al., 2003). (b) Detail map showing an overview of the sampled coal mines. Locations of samples investigated during this study are marked in bold. (c) Regional overview of the Donets Basin in Europe.

ing previous studies (e.g. Stovba and Stephenson, 1999; Stephenson et al., 2001; Sachsenhofer et al., 2003; Izart et al., 2006; Misch et al., 2016). Hence, they offer a perfect opportunity to evaluate multiple influencing factors on coal stability and to develop a nanoindentation testing routine for inhomogeneous, organic matter-rich samples.

\section{Geological Setting}

The Donets Basin (Fig. 1) is a Late Devonian rift structure and forms the south-eastern part of the Pripyat-DnieprDonets-Karpinsky Basin located within the eastern European craton (Stovba and Stephenson, 1999; Stephenson et al., 2001). A detailed chrono- and lithostratigraphic overview of the Donets Basin is given in Sachsenhofer et al. (2003) and Misch et al. (2016). Devonian pre- and syn-rift rocks with a thickness of $750 \mathrm{~m}$ form the margin of the basin, which reaches depths up to $5 \mathrm{~km}$ at its centre. The basement consists of Precambrian crystalline rocks of the eastern European craton, which are overlain by middle Devonian to Carbonif- erous rocks (Chekunov et al., 1993; Maystrenko et al., 2003). The Carboniferous succession is up to $14 \mathrm{~km}$ thick and subdivided into lithostratigraphic units named suites A, B, C, to $\mathrm{P}$ (Lutugin and Stepanov, 1913; Fig. 2). The coal-bearing sequence is formed by fluvial sandstone, marine limestone or mudstone, and deltaic mudstone and siltstone (Sachsenhofer et al., 2003). Marine deposits are more common in the eastern than in the western part of the basin. In general, coal seams and intercalations of coal exist throughout the Carboniferous succession. The lower Serpukhovian (suite C) and Moscovian successions (suites $\mathrm{K}$ to $\mathrm{M}$ ) are particularly rich in coal (Levenshtein et al., 1991; see Fig. 2). Serpukhovian coal seams are concentrated in a narrow NW-SE trending zone along the southwestern basin margin (Shulga, 1981; Fig. 1) where accumulation occurred during a regressivetransgressive cycle in a roughly $10 \mathrm{~km}$ wide shore-zone dissected by several NE trending rivers discharging into a nearby shallow sea in the central Donets Basin (Sachsenhofer et al., 2012). The high amounts of inertinite and liptinite, as well as usually very low ash yields and low to moder- 


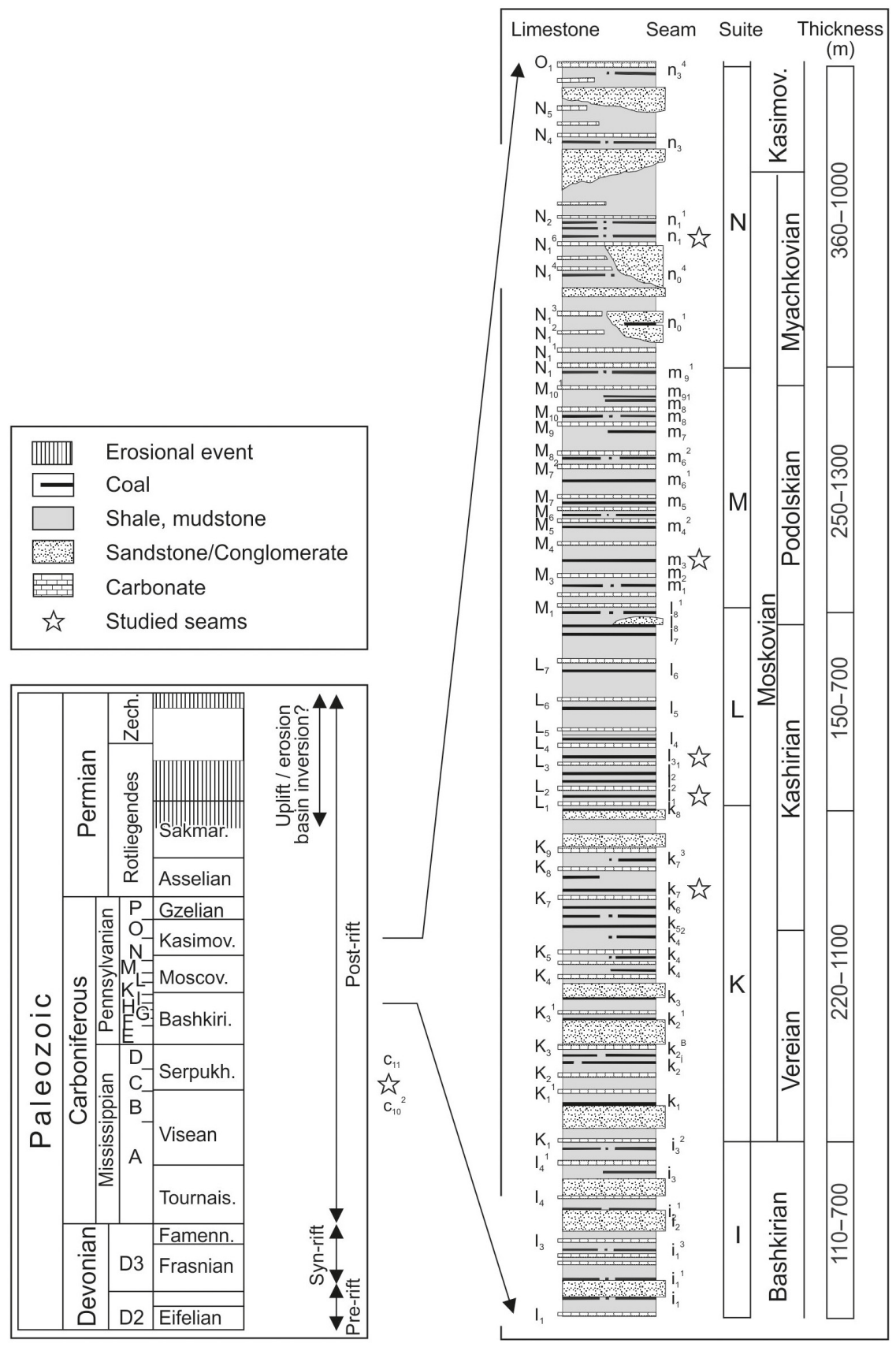

Figure 2. Chrono- and lithostratigraphy of the Donets Basin. Considerable magmatic and tectonic events are shown (Stovba and Stephenson, 1999). For the Moscovian sequence a detailed stratigraphic column is given (after Sachsenhofer et al., 2003, 2012). The studied seams are marked with star symbols.

ate sulphur contents are characteristic for Serpukhovian coals (Sachsenhofer et al., 2003). In contrast, Moscovian seams are generally rich in vitrinite macerals and show high ash yields and variable sulphur contents, related to changing depositional systems with varying marine influence (Sachsenhofer et al., 2003).

The Carboniferous succession in the Donets Basin is of great economic importance; it hosts about 130 economic coal seams, each with a thickness between 0.45 and $2.5 \mathrm{~m}$, summing up to a total net thickness of about $60 \mathrm{~m}$ (Ritenberg, 1972). Most coal fields of the Donets Basin contain high amounts of methane (from 8-10 to $25-37 \mathrm{~m}^{3} \mathrm{t}^{-1}$; Sachsenhofer et al., 2003), which, apart from mine safety issues, constitute a high inherent potential for coal bed methane production (Privalov et al., 2007). 


\section{Experimental}

\subsection{Coal Samples}

The investigated coal samples were collected from wellstudied seam profiles in the (south-)western part of the Donets Basin (Table 1; sampling locations are shown in Fig. 1, for stratigraphic assignment see Fig. 2). Twelve coal samples from Moscovian (11) and Serpukhovian (1) seams were selected based on their vitrinite reflectance (VR) obtained by Sachsenhofer et al. (2003). The selected coals cover a maturity range from 0.62 to $1.47 \% \mathrm{Rr}$ (Table 1 ). The coal specimen were embedded in epoxy resin and prepared as polished sections (final polishing steps with 9, 3,1 $\mu \mathrm{m}$ diamond polishing suspension and $0.05 \mu \mathrm{m}$ micropolish powder). Individual macerals were identified in an optical microscope under white reflected light (no oil immersion), and colormarked to ensure the correct identification during the nanoindentation procedure. No oil immersion was used to enable color-marking.

\subsection{Nanoindentation}

The nanoindentation tests were performed using a Hysitron (now Bruker) Triboscope system with the transducer being mounted on the scanner head of a Digital Instruments (now Bruker) D3100 atomic force microscope, allowing for surface scans. A Cube Corner diamond tip with a tip radius of approximately $200 \mathrm{~nm}$ was used as indenter. Surface scans generated with the Cube Corner tip provided sufficient information to identify suitably flat areas without scratches or other disturbing topography features that might influence the obtained material parameters. The area function of the Cube Corner was calibrated using a fused silica standard following the Oliver-Pharr method (1992). All indentation tests were performed in load control mode with a trapezoidal loading profile to a maximum load of $1000 \mu \mathrm{N}$ held for $10 \mathrm{~s}$ and loading/unloading rates of $500 \mu \mathrm{N} \mathrm{s}^{-1}$. To reduce the influence of thermal instrumental drift, fast loading and unloading sequences were selected, while the holding time of $10 \mathrm{~s}$ at maximum load was chosen to minimize the influence of creep during unloading (Fig. 3). To exclude surface effects or other measurement bias (e.g. due to unintentional indentation of mineral grains embedded in organic matter), all results were quality-checked based on the obtained load-displacement curves that can be regarded as material-characteristic finger prints. Hardness $(H)$ and reduced elastic modulus $\left(E_{\mathrm{r}}\right)$ were determined using the method proposed by Oliver and Pharr (1992). $H$ is defined as the resistance of a material against external force. It is calculated following Eq. (1):

$H=\frac{P_{\max }}{A}$

where $P_{\max }$ is the maximum load applied on the projected contact area $(A)$ between indenter and material. $A$ is calculated from the tip area function and the indentation depth
Table 1. List of samples including information on stratigraphic assignment, measured vitrinite reflectance (VR) and indented maceral groups ( $v=$ Vitrinite; $i=$ Inertinite; $1=$ Liptinite).

\begin{tabular}{lllrl}
\hline Sample & Mine & Stratigraphy & $\begin{array}{r}\text { VR } \\
{[\% \mathrm{Rr}]}\end{array}$ & Indented \\
\hline n1_2 & Butovskaya & Moscovian & 0.83 & $\mathrm{v}, \mathrm{i}, 1$ \\
m3_4 & Bazhanova & Moscovian & 1.10 & $\mathrm{v}, \mathrm{i}$ \\
m3_5 & Bazhanova & Moscovian & 1.21 & $\mathrm{v}$ \\
m3_8 & Bazhanova & Moscovian & 1.23 & $\mathrm{v}$ \\
13_11 & Almaznaya & Moscovian & 0.87 & 1 \\
11_2 & Dimitrova & Moscovian & 0.76 & $\mathrm{v}$ \\
11_4 & Dimitrova & Moscovian & 0.76 & $\mathrm{v}, 1$ \\
11_9 & Dimitrova & Moscovian & 0.71 & $\mathrm{v}, 1$ \\
11_4 & Novogrodovskaya & Moscovian & 0.69 & $\mathrm{v}, 1$ \\
11_2 & 13_bis & Moscovian & 1.47 & $\mathrm{v}$ \\
k7_3 & Centralnaya & Moscovian & 0.93 & $\mathrm{v}, 1$ \\
c10_2 & Yuzho-Donbasskaya & Serpukhovian & 0.62 & $\mathrm{v}, \mathrm{i}, 1$ \\
\hline
\end{tabular}

(h) into the sample surface at maximal load. $E_{\mathrm{r}}$ is obtained by evaluation of the load-displacement curves according to Eq. (2). Therein, the contact stiffness $S$ describes the slope of a tangent that is fitted to the elastic unloading curve segment.

$E_{\mathrm{r}}=\frac{\sqrt{\pi}}{2} \frac{S}{\sqrt{A}}$

During the indentation procedure the diamond tip is also elastically deformed, as it is not entirely rigid. This effect is considered trough Eq. (3):

$\frac{1}{E_{\mathrm{r}}}=\frac{1-v^{2}}{E}+\frac{1-v_{\mathrm{i}}^{2}}{E_{\mathrm{i}}}$

where $E$ is the Young's modulus of the sample and $v$ denominates its Poisson's ratio. $E_{\mathrm{i}}$ and $v_{\mathrm{i}}$ are the known material properties of the indenter tip. However, for soft materials $E$ and $E_{\mathrm{r}}$ are almost equal, as the deformation of the indenter tip can be neglected in this case. Therefore, and because the Poisson's ratios of macerals are not known, this study utilizes $E_{\mathrm{r}}$ as material parameter.

\subsection{Inertinite reflectance measurements}

Three coal samples with different ranks (Table 1) were selected for inertinite reflectance measurements. The measurement of random inertinite reflectance in oil (IR) was performed using a magnification of $100 \times$ in non-polarized light at a wavelength of $546 \mathrm{~nm}$ (Taylor et al., 1998). Inertinite reflectance measurements were compared to nanoindentation results to investigate the relationship between IR, $H$ and $E_{\mathrm{r}}$ for various inertinite sub-macerals. 


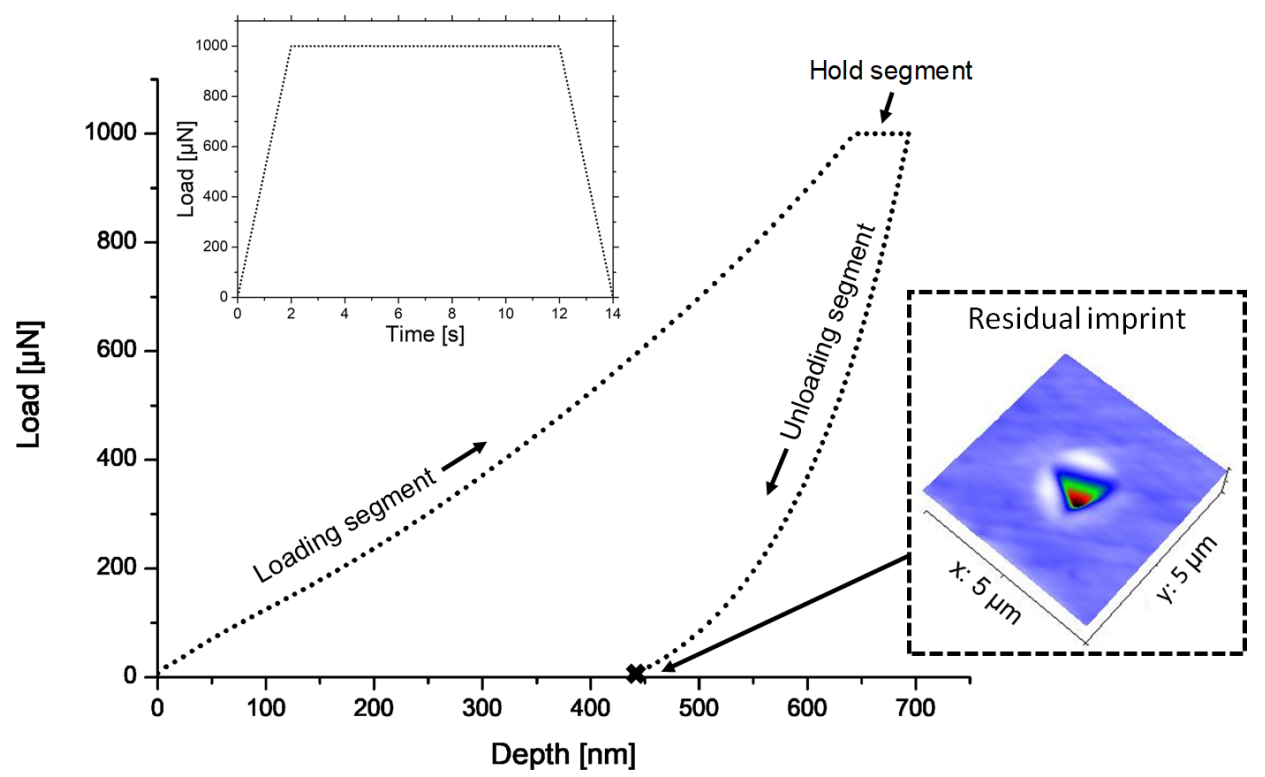

Figure 3. Example of a load-displacement curve, its trapezoidal loading profile and a 3-D-view of the resulting indent.
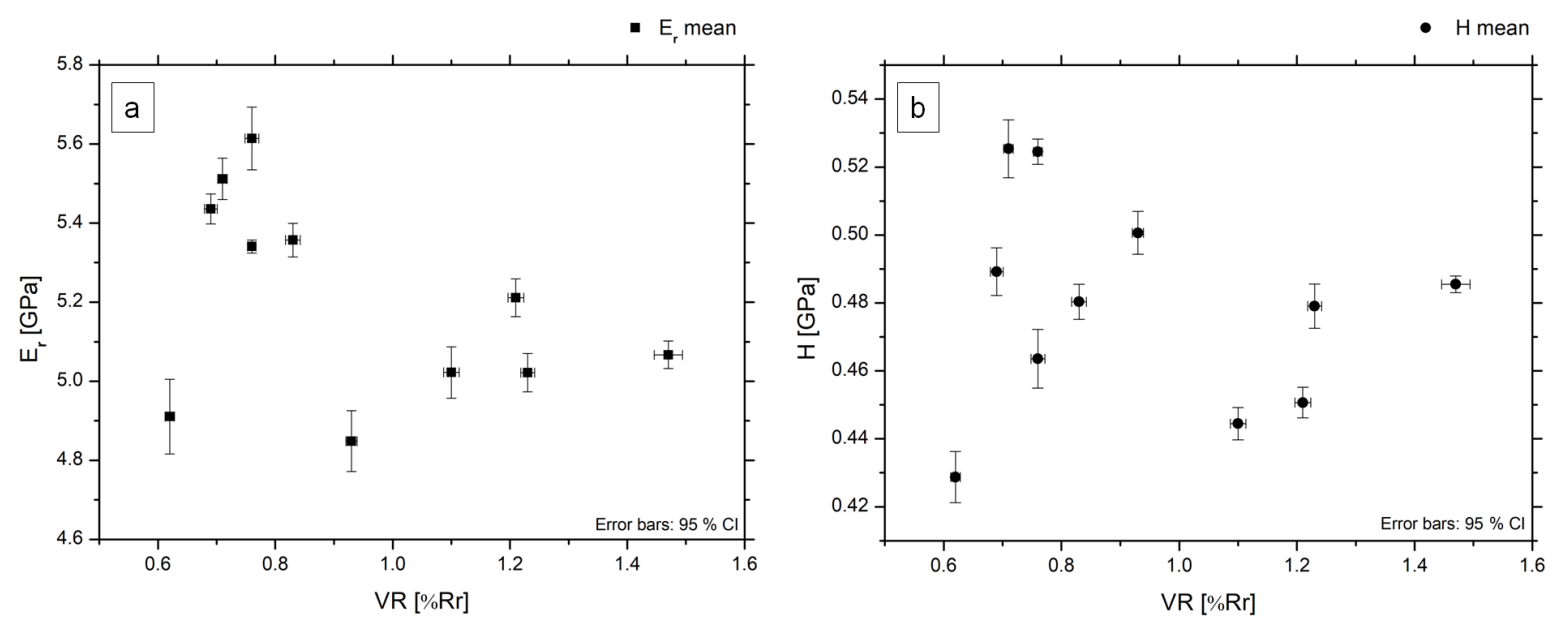

Figure 4. $E_{\mathrm{r}}(\mathbf{a})$ and $H(\mathbf{b})$ obtained for vitrinites from 11 samples with varying maturity $(0.62$ to $1.47 \% \mathrm{Rr})$. $(\mathrm{CI}=\mathrm{Confidence}$ interval).

\section{Results}

\subsection{Vitrinite}

The indentation results indicate that the obtained average $H$ and $E_{\mathrm{r}}$ values of vitrinites do not follow a clear maturity trend (Fig. 4; Table 2). The lowest $H$ and $E_{\mathrm{r}}$ averages are observed in the low rank coals $(0.62 \% \mathrm{Rr})$, with values of $0.43 \pm 0.03$ and $4.91 \pm 0.37 \mathrm{GPa}$, respectively. Both parameters vary considerably at $0.62 \% \mathrm{Rr}$. Medium rank coals $(0.69-0.76 \% \mathrm{Rr})$ show the highest $H$ and $E_{\mathrm{r}}$ averages. The obtained average $H$ and $E_{\mathrm{r}}$ values at $1.47 \% \mathrm{Rr}$ are $0.48 \pm 0.01$ and $5.06 \pm 0.2 \mathrm{GPa}$, respectively, and hence comparatively lower compared to samples of medium rank. Generally, vitrinites show elasto-plastic behavior at all maturity levels (Fig. 5).

\subsection{Inertinite}

$H$ and $E_{\mathrm{r}}$ values obtained from inertinites do not follow a maturity trend (Table 3). However, a linear correlation between the obtained material parameters and measured inertinite reflectance (1.67-3.76\%Rr) is observed (Fig. 6). IR is mainly dependent on the investigated sub-maceral type. Semifusinite shows the lowest reflectance values, while macrinite shows intermediate reflectance. Inertodetrinite and pyrofusinite exhibit the highest reflectance values. Variable shapes of the load-displacement curves illustrate that the deformation behaviour changes from elasto-plastic to mainly elastic with increasing IR (Fig. 7). 
Table 2. Obtained $H$ and $E_{\mathrm{r}}$ averages for vitrinite, including standard deviations (SD) calculated from the respective number of measurements $(n)$.

\begin{tabular}{llrrrrrr}
\hline Sample & Mine & $\begin{array}{r}\mathrm{VR} \\
{[\% \mathrm{Rr}]}\end{array}$ & $\begin{array}{r}E_{\mathrm{r}} \\
{[\mathrm{GPa}]}\end{array}$ & $\begin{array}{r}\mathrm{SD} \\
{[\mathrm{GPa}]}\end{array}$ & $\begin{array}{r}H \\
{[\mathrm{GPa}]}\end{array}$ & $\begin{array}{r}\text { SD } \\
{[\mathrm{GPa}]}\end{array}$ & $n$ \\
\hline $\mathrm{n} 1 \_2$ & Butovskaya & 0.83 & 5.36 & 0.13 & 0.48 & 0.02 & 36 \\
m3_4 & Bazhanova & 1.10 & 5.02 & 0.23 & 0.44 & 0.02 & 52 \\
m3_5 & Bazhanova & 1.21 & 5.21 & 0.13 & 0.45 & 0.01 & 30 \\
m3_8 & Bazhanova & 1.23 & 5.02 & 0.13 & 0.48 & 0.02 & 30 \\
11_2 & Dimitrova & 0.76 & 5.34 & 0.05 & 0.52 & 0.01 & 34 \\
11_4 & Dimitrova & 0.76 & 5.61 & 0.19 & 0.46 & 0.02 & 25 \\
11_9 & Dimitrova & 0.71 & 5.51 & 0.14 & 0.53 & 0.02 & 30 \\
11_4 & Novogrodovskaya & 0.69 & 5.44 & 0.09 & 0.49 & 0.02 & 26 \\
11_2 & 13_bis & 1.47 & 5.07 & 0.20 & 0.49 & 0.01 & 34 \\
k7_3 & Centralnaya & 0.93 & 4.85 & 0.27 & 0.50 & 0.02 & 48 \\
c10_2 & Yuzho-Donbasskaya & 0.62 & 4.91 & 0.37 & 0.43 & 0.03 & 62 \\
\hline
\end{tabular}

Table 3. $H$ and $E_{\mathrm{r}}$ averages determined for various inertinite sub-macerals, including standard deviations (SD) calculated from the respective number of measurements $(n)$. Vitrinite reflectance (VR), indicative for the thermal maturity of the whole coal sample, was adopted from Sachsenhofer et al. (2003). Inertinite reflectance values (IR) of investigated inertinite macerals were measured during this study and reflect the conditions during pre-depositional wildfires, rather than thermal maturity related to burial. Note that inertinite reflectance refers to the actually indented macerals.

\begin{tabular}{llrlrrrrrr}
\hline Sample & Mine & $\begin{array}{r}\text { VR } \\
{[\% \mathrm{Rr}]}\end{array}$ & Sub-maceral & $\begin{array}{r}\text { IR } \\
{[\% \mathrm{Rr}]}\end{array}$ & $\begin{array}{r}E_{\mathrm{r}} \\
{[\mathrm{GPa}]}\end{array}$ & $\begin{array}{r}\mathrm{SD} \\
{[\mathrm{GPa}]}\end{array}$ & $\begin{array}{r}H \\
{[\mathrm{GPa}]}\end{array}$ & $\begin{array}{r}\mathrm{SD} \\
{[\mathrm{GPa}]}\end{array}$ & $n$ \\
\hline n1_2 & Butovskaya & 0.83 & Inertodetrinite & 3.13 & 14.55 & 0.21 & 3.84 & 0.18 & 4 \\
m3_4 & Bazhanova & 1.10 & Semifusinite & 1.86 & 7.81 & 0.30 & 1.64 & 0.06 & 7 \\
m3_4 & Bazhanova & 1.10 & Inertodetrinite & 3.04 & 11.95 & 0.56 & 3.29 & 0.15 & 6 \\
m3_4 & Bazhanova & 1.10 & Makrinite & 1.70 & 6.68 & 0.54 & 1.19 & 0.21 & 9 \\
m3_4 & Bazhanova & 1.10 & Semifusinite & 1.70 & 5.55 & 0.07 & 0.84 & 0.02 & 5 \\
c10_2 & Yuzho-Donbasskaya & 0.62 & Semifusinite & 1.90 & 7.15 & 0.08 & 1.94 & 0.09 & 5 \\
c10_2 & Yuzho-Donbasskaya & 0.62 & Makrinite & 1.69 & 5.46 & 0.05 & 0.92 & 0.06 & 9 \\
c10_2 & Yuzho-Donbasskaya & 0.62 & Pyrofusinite & 3.74 & 20.03 & 0.08 & 4.83 & 0.15 & 4 \\
c10_2 & Yuzho-Donbasskaya & 0.62 & Pyrofusinite & 2.44 & 9.31 & 0.64 & 2.86 & 0.20 & 7 \\
c10_2 & Yuzho-Donbasskaya & 0.62 & Semifusinite & 1.67 & 6.96 & 0.21 & 1.60 & 0.08 & 5 \\
\hline
\end{tabular}

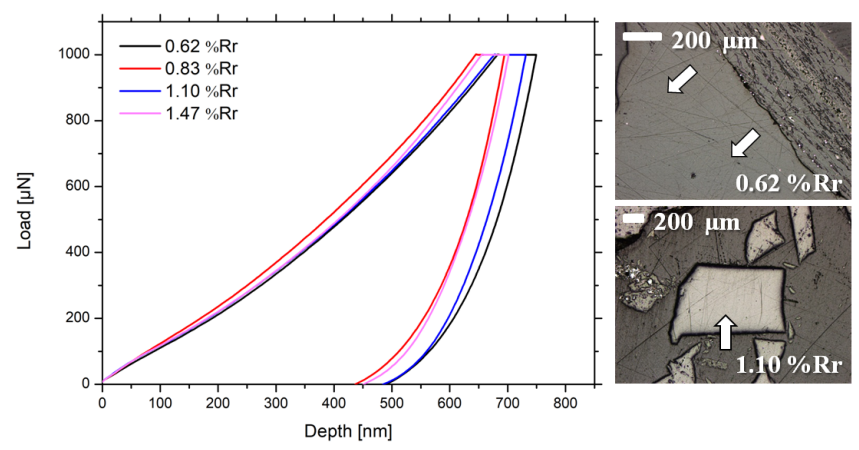

Figure 5. Averaged load-displacement curves for vitrinites at different coal rank. Slightly differing deformation behaviour is indicated by the individual curve shapes. However, a general elasto-plastic behaviour dominates at all maturity ranges. The insets show micrographs of typical indentation spots.

\subsection{Liptinite}

Sporinite is the most abundant liptinite maceral in the selected coals and hence indentation tests were mainly conducted on sporinites. The lowest value for $H$ was determined for the least mature sample $(0.62 \% \mathrm{Rr})$, whereas the highest values for both $H$ and $E_{\mathrm{r}}$ occur at $0.71 \% \mathrm{Rr}$. After the peak, a decrease in the values of $E_{\mathrm{r}}$ and (to a lesser degree) $H$ is observed. $E_{\mathrm{r}}$ and $H$ averages at 0.83 and $0.92 \% \mathrm{Rr}$ are comparably low (Table 4; Fig. 8). At $0.93 \%$ Rr, the obtained $E_{\mathrm{r}}$ and (to a lesser degree) $H$ values show a multimodal frequency distribution (Fig. 9). The material behavior of liptinites can be described as elasto-plastic with dominance of the plastic deformation part at all maturity-levels (Fig. 10). Loaddisplacement curves of liptinites exhibit the largest amount of energy dissipation and highest indentation depths of all maceral groups. 
Table 4. $H$ and $E_{\mathrm{r}}$ averages obtained from sporinites, including standard deviations (SD) calculated from the respective number of measurements $(n)$.

\begin{tabular}{llrrrrrr}
\hline Sample & Mine & $\begin{array}{r}\mathrm{VR} \\
{[\% \mathrm{Rr}]}\end{array}$ & $\begin{array}{r}E_{\mathrm{r}} \\
{[\mathrm{GPa}]}\end{array}$ & $\begin{array}{r}\mathrm{SD} \\
{[\mathrm{GPa}]}\end{array}$ & $\begin{array}{r}H \\
{[\mathrm{GPa}]}\end{array}$ & $\begin{array}{r}\mathrm{SD} \\
{[\mathrm{GPa}]}\end{array}$ & $n$ \\
\hline $\mathrm{n} 1 \_2$ & Butovskaya & 0.83 & 6.09 & 0.27 & 0.39 & 0.02 & 18 \\
$13 \_11$ & Almaznaya & 0.87 & 4.39 & 0.34 & 0.41 & 0.03 & 25 \\
$11 \_4$ & Dimitrova & 0.76 & 6.25 & 0.43 & 0.42 & 0.02 & 36 \\
$11 \_9$ & Dimitrova & 0.71 & 6.31 & 0.29 & 0.43 & 0.02 & 27 \\
$11 \_4$ & Novogrodovskaya & 0.69 & 4.28 & 0.14 & 0.38 & 0.01 & 25 \\
k7_3 & Centralnaya & 0.93 & 3.69 & 0.30 & 0.38 & 0.03 & 41 \\
c10_2 & Yuzho-Donbasskaya & 0.62 & 5.73 & 0.70 & 0.35 & 0.05 & 45 \\
\hline
\end{tabular}
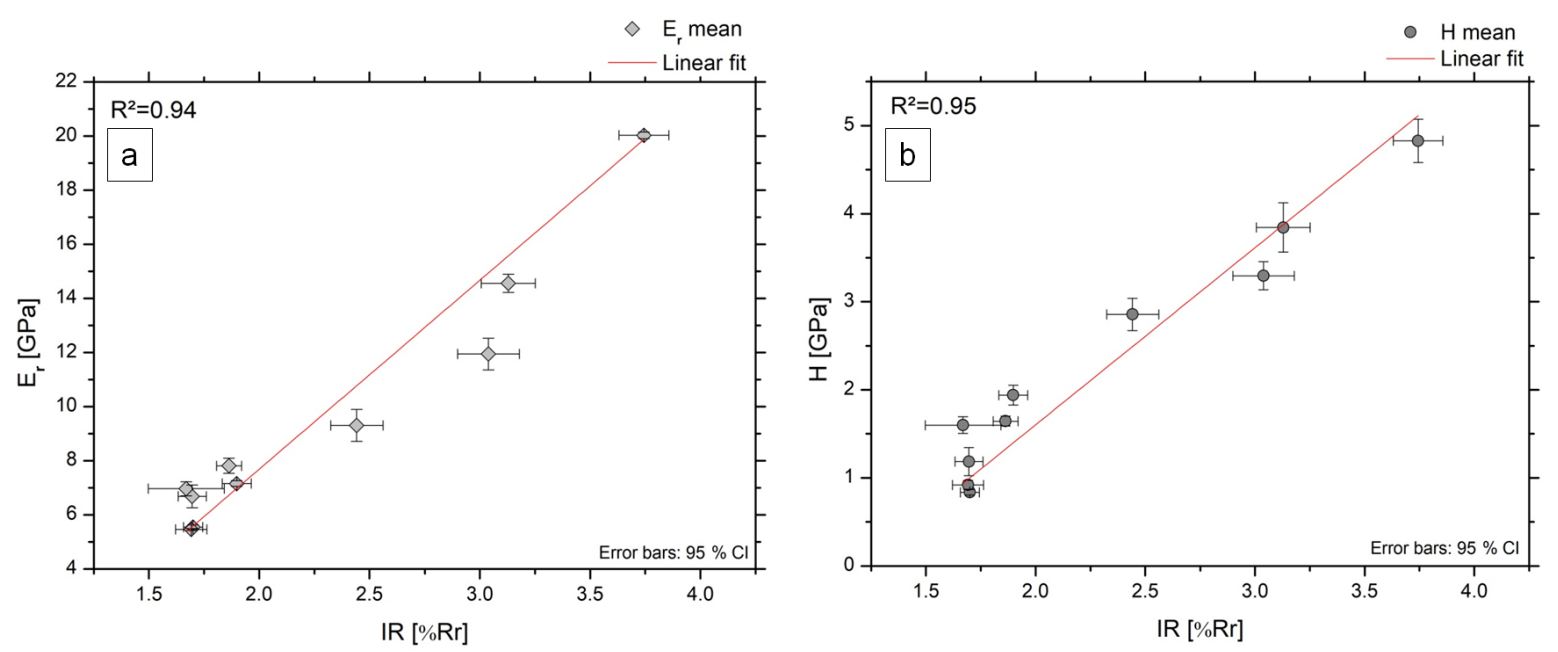

Figure 6. $E_{\mathrm{r}}$ (a) and $H$ (b) obtained for inertinites with varying IR (inertinite reflectance). $(\mathrm{CI}=\mathrm{Confidence} \mathrm{interval).}$

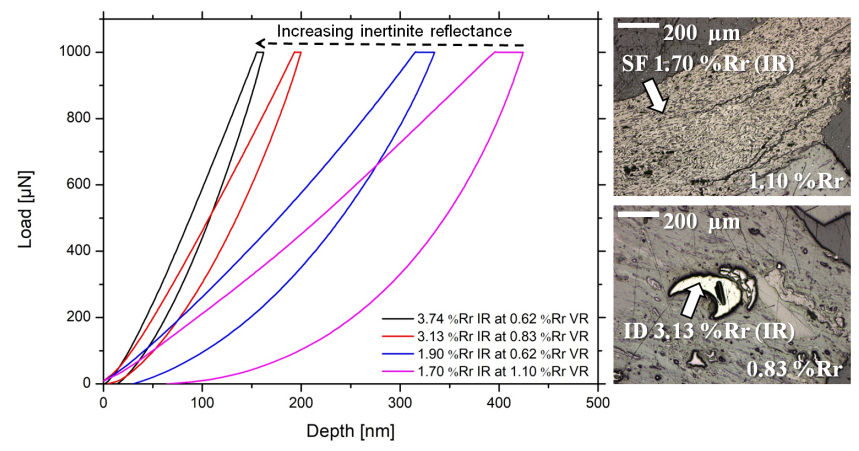

Figure 7. Averaged load-displacement curves for inertinites at different coal ranks. The deformation behaviour changes rapidly with increasing IR, as indicated by the dashed arrow. Insets show different investigated inertinite sub-macerals $(\mathrm{SF}=$ semifusinite; ID = inertodetrinite).

\section{Discussion}

\subsection{Vitrinite}

In general, the coalification process of vitrinites at the bituminous rank is characterized by various changing parameters, including loss of hydrogen- and oxygen-bearing functional groups and volatile matter, increasing aromaticity, decreasing primary porosity and increasing density, which leads to generally increasing organic carbon contents and increased homogenization (e.g. Taylor et al., 1998; Tissot and Welte, 1984). However, the density of vitrinites does not change linearly with ongoing thermal maturation. At the boundary between sub-bituminous to bituminous coal rank, the true density decreases with rank as a result of the devolatilization of mainly heavy oxygen-rich compounds. The density increases again at advanced maturity because hydrogen-rich components are transformed during hydrocarbon generation and the increase of aromatic units leads to a tighter packing of the polymer structure (Taylor et al., 1998; Van Krevelen, 1961). Nevertheless, it might decrease again due to the generation of secondary (nano-)porosity. The mechanical proper- 

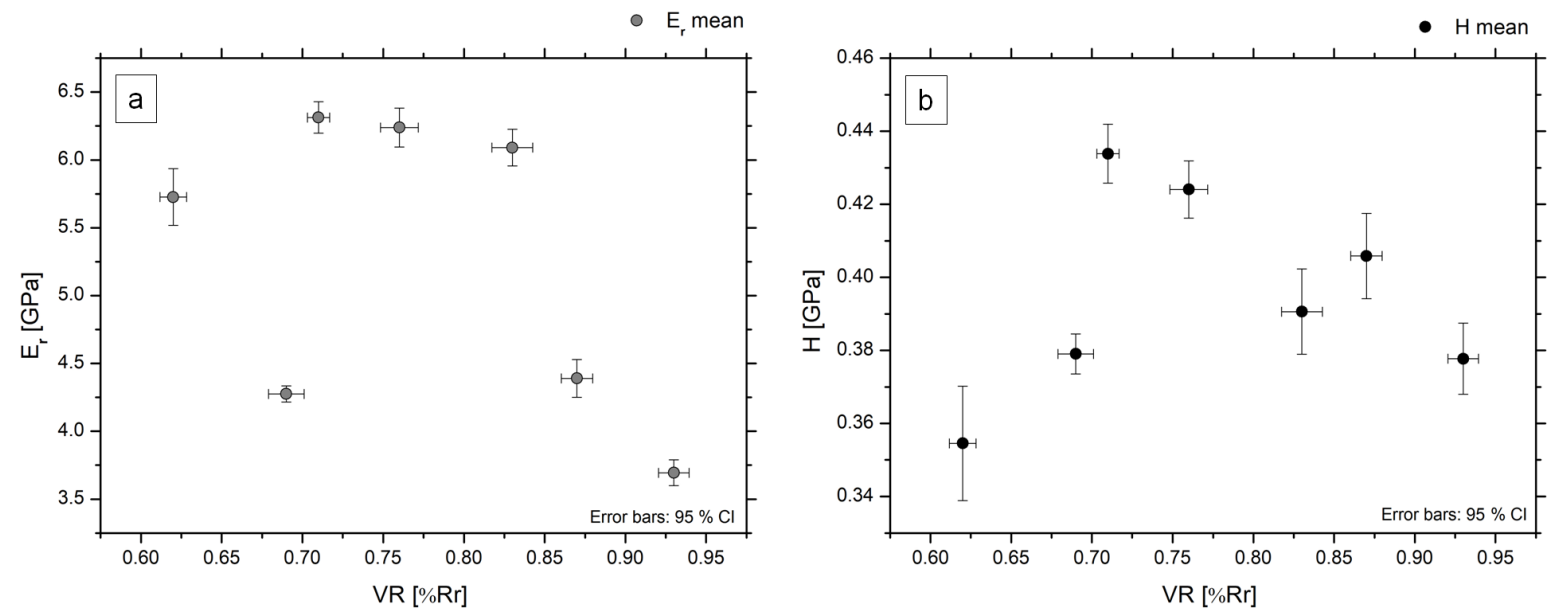

Figure 8. $E_{\mathrm{r}}(\mathbf{a})$ and $H(\mathbf{b})$ obtained for sporinites at varying maturity $(0.62$ to $0.93 \% \mathrm{Rr})$. $(\mathrm{CI}=\mathrm{Confidence}$ interval $)$.
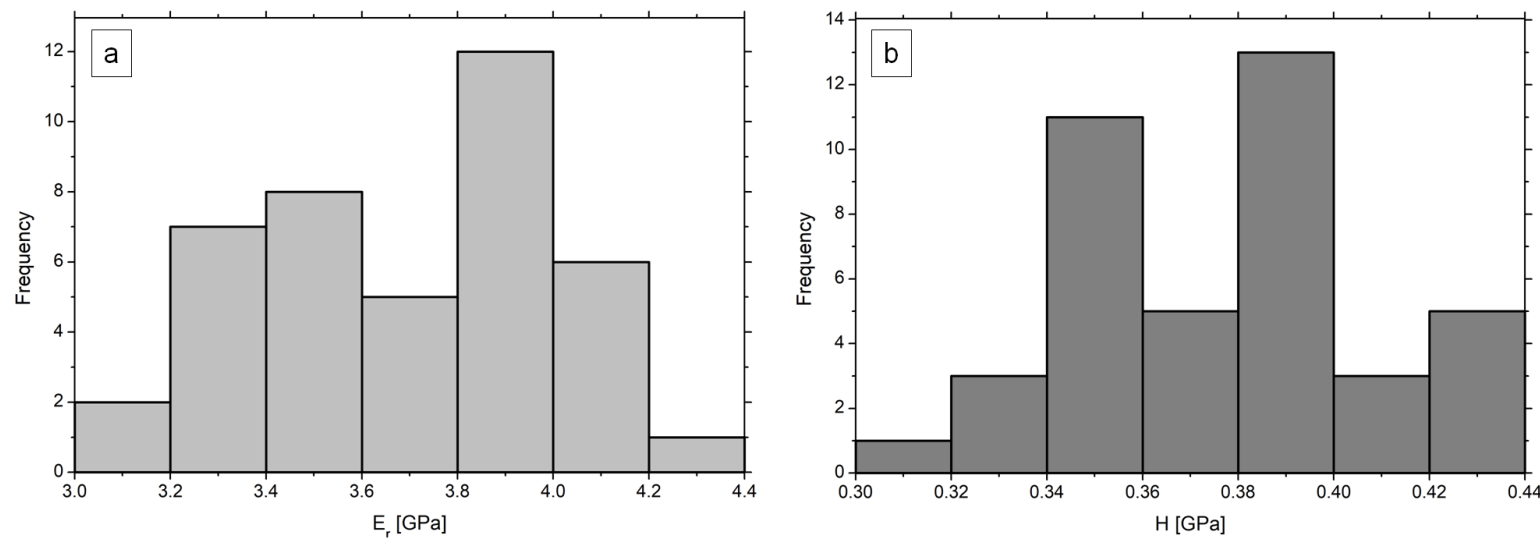

Figure 9. The frequency distribution of the obtained $E_{\mathrm{r}}(\mathbf{a})$ and $H(\mathbf{b})$ values at $0.93 \% \mathrm{Rr}$.

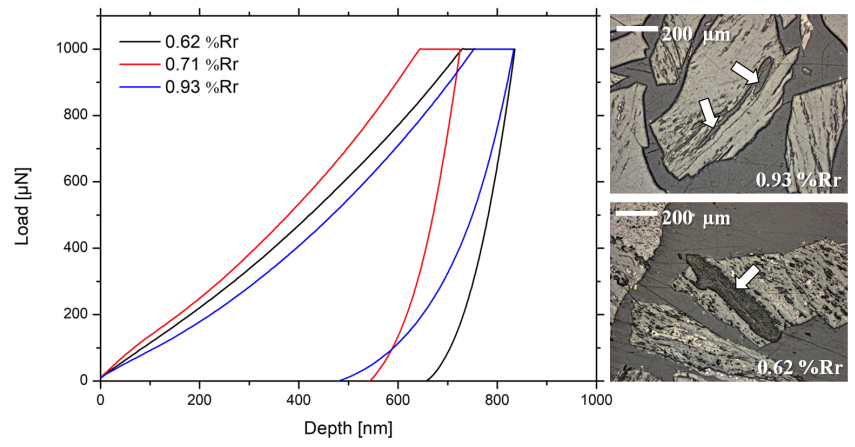

Figure 10. Averaged load-displacement curves for sporinites at different coal ranks. The insets show micrographs of sporinites at lowmedium $(0.62 \% \mathrm{Rr})$ and high rank $(0.93 \% \mathrm{Rr})$.

ties of vitrinite macerals investigated during this study reflect the complex effects described above, rather than a linear maturity trend (Fig. 4a, b). Samples at low to medium rank show largely varying mechanical properties, whereas less scatter- ing results at advanced maturity $(>1.0 \% \mathrm{Rr})$ point to increasing homogeneity of the organic matter structure at this stage, reflected also by a more uniform geochemical composition (e.g. Misch et al., 2016). Apart from maturation-related processes such as devolatilization (decreases primary porosity) and hydrocarbon generation (increases secondary porosity), changing mineral matter contents, best approximated by the ash yield, might affect porosity and relative density of vitrinites especially at an early mature stage. The obtained $E_{\mathrm{r}}$ and (to a lesser degree) $H$ values correlate with ash yields (Fig. 11a, b; ash yield data from Sachsenhofer et al., 2003) at low to medium rank. Hence, the depositional setting can be considered an equally important influencing factor for the mechanical properties of vitrinites at this maturity stage.

\subsection{Inertinite}

The highest average values for $H$ and $E_{\mathrm{r}}$ were obtained from inertinites. Apparently, the mechanical properties of inertinites are not primarily controlled by the coal rank but correlate well with the measured inertinite reflectance. Re- 

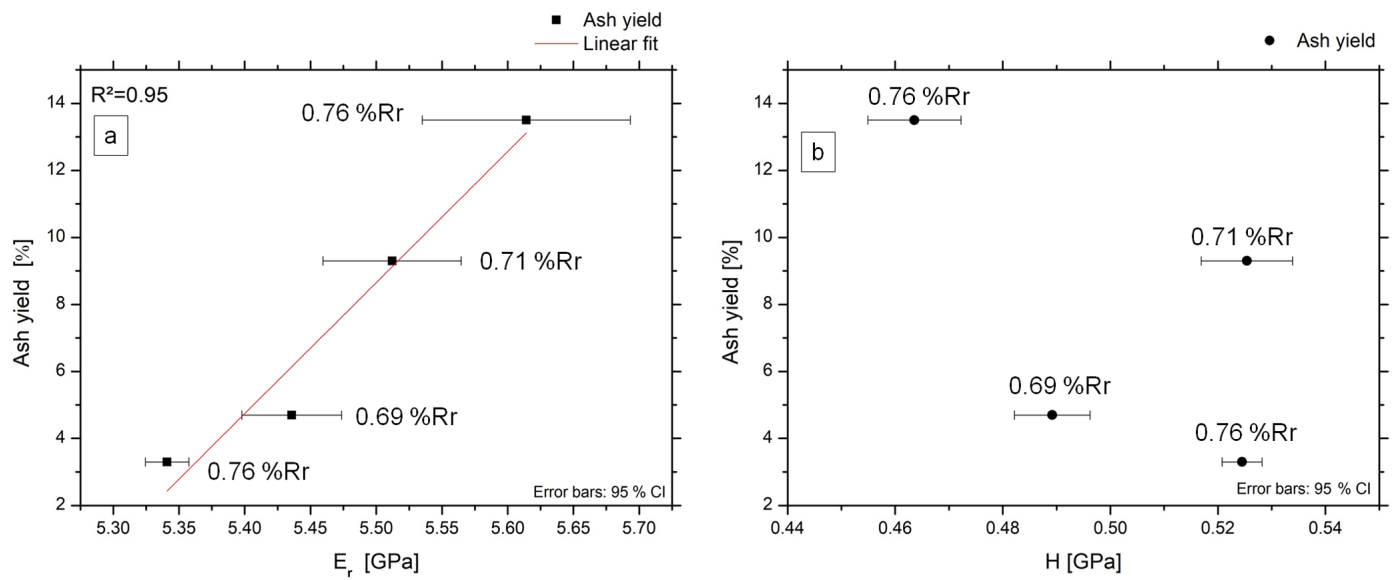

Figure 11. Correlation between ash yield (data from Sachsenhofer et al., 2003), $E_{\mathrm{r}}$ (a) and $H$ (b) of vitrinite macerals. Note that samples of equal maturity (and hence chemical composition) are displayed for comparison. $(\mathrm{CI}=$ Confidence interval $)$.

flectance studies of recent wildfire charcoals and experimental pyrolysis studies on charcoalified wood prove that inertinite reflectance increases with burning temperature, regardless of its morphology (Scott and Glasspool, 2007). A wildfire might produce a spectrum of different temperatures up to $1000^{\circ} \mathrm{C}$ depending on the grade of exposition (Pyne et al., 1996). Zickler et al. (2006) studied the influence of artificial pyrolysis treatments on the mechanical properties of wood cells via nanoindendation. Between 500 and $900^{\circ} \mathrm{C}$ they described a continuous rise of $E_{\mathrm{r}}$. A continuous increase could also be observed in $H$ at the pyrolysis temperature between 220 and $700{ }^{\circ} \mathrm{C}$. Furthermore, a transition from elasto-plastic to mainly elastic material behaviour with rising temperature according to the load-displacement curves was described by the authors. These findings are reflected by the clear correlation of mechanical properties and deformation behaviour with the measured inertinite reflectance of the investigated samples. Zickler et al. (2006) interpreted this trend as an increase of covalent carbon-bonding and a glass-like structure characterized by randomly cross-linked aromatic carbon sheets. Hence, the main controlling factor for the material behaviour of inertinite is the temperature exposure during paleo-wildfire events.

\subsection{Liptinite}

The indentation results of liptinites indicate a non-linear relationship with maturity. Both $H$ and $E_{\mathrm{r}}$ of sporinites increase with maturity from low to medium rank (up to $0.7 \% \mathrm{Rr}$; Fig. 8a, b). The sample at $0.71 \% \mathrm{Rr}$ exhibits a maximum of both parameters, likely related to progressing organization, dehydration and decarboxylation processes of the biopolymers, predominantly occurring at low to medium rank. A gradual decrease of both $E_{\mathrm{r}}$ and $H$ occurs from 0.76 to $0.83 \% \mathrm{Rr}$, and the lowest $E_{\mathrm{r}}$ value occurs at $0.93 \% \mathrm{Rr}$ (Fig. 8a). The sharp decrease in measured reduced elas- tic moduli might indicate the onset of thermal cracking related to hydrocarbon generation, associated with the loss of aliphatic chains and the formation of isolated aromatic rings (Yule et al., 2000). The multimodal distribution of measured $E_{\mathrm{r}}$ and $H$ (Fig. 9a, b) values points to an anisotropic behaviour that is caused by structural reorganisation and polymerisation of the aromatic units that leads to the formation of sheets (Yule et al., 2000). The outlier of $E_{\mathrm{r}}$ at $0.69 \% \mathrm{Rr}$ is likely caused by changes in the depositional environment, as Misch et al. (2016) reported elevated organic $S$ contents at the expense of $\mathrm{C}$, related to an increased marine/brackish influence on the Novogrodovskaya seam during peat formation that agrees with findings from Sachsenhofer et al. (2003). Various authors (e.g. Orr, 1986; Tomić et al., 1995) postulated earlier hydrocarbon generation for coals high in organic sulphur. Therefore, the low $E_{\mathrm{r}}$ and $H$ averages determined for the Novogrodovskaya sample can be interpreted as earlier onset of transformation reactions related to hydrocarbon generation.

\section{Conclusion}

The present results indicate that apart from maturity, multiple parameters control the mechanical properties of macerals. In case of inertinites, the prevailing conditions (temperature, exposure) during paleo-wildfires represent the main controlling factor for the mechanical properties. $E_{\mathrm{r}}$ and $H$ of liptinites are strongly influenced by transformational processes related to devolatilization at low to medium rank, and later hydrocarbon generation. Furthermore, variations in the depositional environment (e.g. increased organic sulphur content due to brackish conditions) might play an additional role. The mechanical properties of vitrinites show no clear correlation with maturity, as a result of multiple influencing factors such as mineral matter inclusions, depositional conditions, and transformation of the organic matter structure and possibly 
the generation of nanoporosity at advanced maturity. In order to achieve a deeper understanding of the interdependency between mechanical properties and microstructural features (e.g. nanoporosity, mineral inclusions), advanced characterization techniques such as transmission electron microscopy (TEM) are required, which will be a focus of future research.

Data availability. The datasets generated during the current study are available from the corresponding author on reasonable request.

Competing interests. The authors declare that they have no conflict of interest.

Special issue statement. This article is part of the special issue "European Geosciences Union General Assembly 2018, EGU Division Energy, Resources \& Environment (ERE)"'. It is a result of the EGU General Assembly 2018, Vienna, Austria, 8-13 April 2018.

Acknowledgements. The authors are grateful for financial support provided by the funding program dedicated to interdisciplinary studies at Montanuniversitaet Leoben. Jürgen Eckert is thanked for fruitful discussions on the mechanical characteristics of C-based specimen, while Sabine and Felix Feuchter helped with the preparation of polished blocks. Franz Hubner, Robin Neubauer and Silke Modritsch are thanked for the adjustment of the samples. Thoughtful reviews of Sid-Ali Ouadfeul and one anonymous referee are gratefully acknowledged. This work was funded by the Austrian science fund FWF (grant no. P 29310-NBL).

Edited by: Kristen Mitchell

Reviewed by: Sid-Ali Ouadfeul and one anonymous referee

\section{References}

Borodich, F. M., Bull, S. J., and Epshtein, S. A.: Nanoindentation in studying mechanical properties of heterogeneous materials, J. Min. Sci.+, 51, 470-476, https://doi.org/10.1134/s1062739115030072, 2015.

Chekunov, A. V., Kaluzhnaya, L. T., and Ryabchun, L. I.: The Dniepr-Donets paleorift, Ukraine, deep structures and hydrocarbon accumulations, J. Petrol. Geol., 16, 183-196, https://doi.org/10.1111/j.1747-5457.1993.tb00105.x, 1993.

Epshtein, S. A., Borodich, F. M., and Bull, S. J.: Evaluation of elastic modulus and hardness of highly inhomogeneous materials by nanoindentation, S. J. Appl. Phys. A., 119, 325-335, https://doi.org/10.1007/s00339-014-8971-5, 2015.

Izart, A., Sachsenhofer, R. F., Privalov, V. A., Elie, M., Panova, E. A., Antsiferov, V. A., Alsaab, D., Rainer, T., Sotirov, A., Zdravkov, A., and Zhykalyak, M. V.: Stratigraphic distribution of macerals and biomarkers in the Donets Basin: implications for paleoecology, paleoclimatology and eustacy, Int. J. Coal Geol., 66, 69-107, https://doi.org/10.1016/j.coal.2005.07.002, 2006.
Levenshtein, M. L., Spirina, O. I., Nosova, K. B., and Dedov, V. S.: Map of Coal Metamorphism in the Donetsk Basin (Paleozoic Surface), 1:500 000, Ministry of Geology of the USSR, Kiev, Ukraine, 1991.

Lutugin, L. I. and Stepanov, P. I.: Donets Coal Basin, Geological Committee, Coal Minings in Russia, St. Petersburg, Russia, 112143, 1913.

Maystrenko, Y., Stovba, S., Stephenson, R., Bayer, U., Menyoli, E., Gajewski, D., Huebscher, C., Rabbel,W., Saintot, A., Starostenko, V., Thybo, H., and Tolkunov, A.: Crustal-scale popup structure in cratonic lithosphere: DOBRE deep seismic reflection study of the Donbas fold belt, Ukraine, Geology, 31, 733736, https://doi.org/10.1130/g19329.1, 2003.

Misch, D., Groß, D., Huang, Q., Zaccarini, F., and Sachsenhofer, R. F.: Light and trace element composition of Carboniferous coals from the Donets Basin (Ukraine): An electron microprobe study, Int. J. Coal Geol., 168, 108-118, https://doi.org/10.1016/j.coal.2016.06.004, 2016.

Oliver, W. C. and Pharr, G. M.: An improved technique for determining hardness and elastic modulus using load and displacement sensing indentation experiments, J. Mater. Res., 7, 15641583, https://doi.org/10.1557/jmr.1992.1564, 1992.

Orr, W. L.: Kerogen/asphaltene/sulfur relationships in sulfur-rich Monterey oils, Org. Geochem., 10, 499-516, https://doi.org/10.1016/0146-6380(86)90049-5, 1986.

Privalov, V. A., Panova, E. A., Sachsenhofer, R. F., Izart, A., Antsiferov, A. V., and Antsiferov, V. A.: Delineation of gas prospective sites in the Donets Basin, Ukraine, 69th EAGE Conference \& Exhibition, London, UK, 11-14 June 2007, https://doi.org/10.3997/2214-4609.201401846, 2007.

Pyne, S. J., Andrews, P. L., and Laven, R. D.: Introduction to Wildland Fire, J. Wiley \& Sons, New York, USA, 769 pp., 1996.

Ritenberg, M. I.: Method of the investigation of facies and cycles, edited by: Makedonov, A. V., Correlation of Coalbearing Sediments and Coal Seams in the Donets Basin, Nauka, Leningrad, Russia, 71-95, 1972.

Sachsenhofer, R. F., Privalov, V. A., Izart, A., Elie, M., Kortensky J., Panova E. A., Sotirov, A., and Zhykalyak, M. V.: Petrography and geochemistry of Carboniferous coal seams in the Donets Basin (Ukraine): implications for paleoecology, Int. J. Coal Geol., 55, 225-259, https://doi.org/10.1016/s01665162(03)00112-5, 2003.

Sachsenhofer, R. F., Privalov, V. A., and Panova E. A.: Basin evolution and coal geology of the Donets Basin (Ukraine, Russia): an overview, Int. J. Coal Geol., 89, 26-40, https://doi.org/10.1016/j.coal.2011.05.002, 2012.

Scott, A. C. and Glasspool, I. J.: Observations and experiments on the origin and formation of inertinite group macerals, Int. J. Coal Geol., 70, 53-66, https://doi.org/10.1016/j.coal.2006.02.009, 2007.

Shulga, V. F. (Ed.): Lower Carboniferous Coal Formations of the Donets Basin, Nauka, Moscow, Russia, 176 pp., 1981.

Stephenson, R. A., Stovba, S. M., and Starostenko, V. I.: PripyatDniepr-Donets Basin: implications for dynamics of rifting and the tectonic history of the northern Peri-Tethyan platform, edited by: Ziegler, P. A., Cavazza, W., Robertson, A. H. F., and Crasquin-Soleau, S., Peri-Tethyan Rift/Wrench Basins and Passive Margins: Peri-Tethys Memoir, Paris, France, 6, 369-406, 2001. 
Stovba, S. M. and Stephenson, R. A.: The Donbas Foldbelt: its relationships with the uninverted Donets segment of the Dniepr-Donets Basin, Ukraine, Tectonophysics, 313, 59-83, https://doi.org/10.1016/s0040-1951(99)00190-0, 1999.

Taylor, G. H., Teichmüller, M., Davis A., Diessel, C. F. K., Littke, R., and Robert, P.: Organic Petrology, Borntraeger, BerlinStuttgart, Germany, 704 pp., 1998.

Tissot, B. P. and Welte D. H.: Petroleum Formation and Occurrence, Springer, Berlin, Germany, 699 pp., 1984.

Tomić, J., Behar, F., Vandenbroucke, M., and Tang, Y.: Artificial maturation of a Monterey kerogen (Type II-S) in a closed system and comparison with Type II kerogen: Implications on the fate of sulfur, Org. Geochem., 23, 647-660, https://doi.org/10.1016/0146-6380(95)00043-e, 1995.
Van Krevelen, D. W.: Coal, Elsevier, Amsterdam, the Netherlands, 514 pp., 1961.

Yule, B. L., Roberts, S., and Marshall, J. E. A.: The thermal evolution of sporopollenin, Org. Geochem., 31, 859-870, https://doi.org/10.1016/S0146-6380(00)00058-9, 2000.

Zickler, G. A., Schöberl, T., and Paris, O.: Mechanical properties of pyrolysed wood: A nanoindentation study, Philos. Mag., 86, 1373-1386, https://doi.org/10.1080/14786430500431390, 2006. 